\title{
The Analysis on Continous Development Strategy at Farming Production Centre of Mifee Program In Merauke Regency
}

\author{
IrbaDjaja $^{1,2, *)}$, P. Purwanto. ${ }^{1,3)}$ and H. R.Sunoko ${ }^{1,4)}$ \\ ${ }^{1}$ Doctoral Program of Environmental Science, School of Postgraduate Studies, Diponegoro University, \\ Semarang Indonesia \\ ${ }^{2}$ Faculty of Agrotecknology, Musamus University Merauke Indonesia \\ ${ }^{3}$ Department of Chemical Engineering, Faculty of Engineering, Diponegoro University, Semarang Indonesia \\ ${ }^{4}$ Department of pharmacy, Faculty of Medical, Diponegoro University, Semarang Indonesia
}

\begin{abstract}
Merauke, in 2010, arranged a program of Merauke Integrated Food and Energy Estate (MIFEE) which was an alternative program to solve food crisis and nation's energy oriented to integrated farming development. MIFEE program needed wide enough area that was 1.2 million of acre affecting the enviornment and society. This study aims to arrange an effective, eco-friendly, and continous strategy to develop the Farming Production Centre (KSPP) MIFEE in Merauke. The study for 7 months (November 2016 to June 2017). The analysis methods used were SWOT and AHP. The results show that development strategy of KSPP MIFEE Program in Merauke is Rapid Growth Strategy. This strategy is suitable with position requiring progressive strategy to support growth through some strategies can be implemented; The main strategy is forming special force to manage KSPP MIFEE Program in Merauke involving stake holders to support national food, reduce dynamics at region, and receive aspiration with 0.241 point, and by socializing Program to the residents with 0.221 point, by improving the ability, skill, and capacity of human resources supported by local-wisdom-based education with 0.122 point, by developing eco-friendly farming diversification and low external input that can reduce the resistency of society with 0.114 point.
\end{abstract}

Keywords: strategy, SWOT analysis, MIFEE Program.

\section{INTRODUCTION}

MIFEE program is a wide scale activity of food estate farming using high input managed by modern management, dense capital, and emphasizing local wisdom in terms of environmental management and conservation technique. Farming management is always related to the needs of water supply and land capacity as natural resources connected to each other and factors succeeding farming program. MIFEE final purposes are the improvement food supply in Indonesia, the improvement of Bruto Regional Domectic Product (PDRB) per capita in Merauke and saving National Deficite by reducing food import (1).

Merauke is agraria area and the agriculture sector is a dominant one because the natural resources supply can be the foundation to increase region competitiveness and source income. The width of Merauke based on Regional Rules Number 142011 on the Plan of Spacial Arrangement Merauke in 2010-2030 is $4,679,163.26$ ha $(14.67 \%$ from the width of Papua Province) consisting of 2,724,059.64 ha(58,22\%) protected area and 1,955,103.62 ha. (41,78\%) conservation area. From the total width of Merauke, based on data from Food Crop Department in 2013, the land potential of Merauke was 2,491,821.99 Ha, with wet land potential 1.9 million ha and 591 ha of dry land.

The area development for farming conservation in wide scale cannot be done by government without any stakeholders, privates, and society get involved as the important element of the development at farming development area (2).

The purpose of this study is the arrangement of development strategy on KSPP MIFEE Program in Merauke, and the integrated and continous balance of importance between economic, social, and environmental growth. This strategy is expected to contribute to the development process for environmentally sound area management to realize developing low carbon society.

\section{DATA AND METHODS}

The data used to review the development strategy at KSPP are internal and external condition at KSPP MIFEE Program. This condition includes physical condition (positioning and natural resources), economic, social, culture, civilization, and regional infrastructure.

* Corresponding author: plhdjaja@mail.com 
Formulating development strategy is done by analyzing the data gathered from interview and questionnaires with stakeholders chosen from; BAPPEDA of Merauke, Living Environment Department of Merauke, BPMP2T Merauke, Food Crop Department of Merauke, Public Works Department, Land and Spacial Arrangement Department of Merauke, Fishery Department of Merauke, Food Supply Department, Animal Health and Cattlebreeding Department of Merauke, Scholars from Musamus University Merauke, activist of WWF and self-funded foundation Silva Papua Merauke; to decide policy on continous KSPP MIFEE Program development viewed from ecological, social, economic, and organizational aspects.

The data then are analyzed to decide priority program at KSPP MIFEE Program Merauke by giving points on factors of IFAS and EFAS using Saaty scale based on the consideration of stakeholders followed by strategy formulation using SWOT analysis proceeded with Hierarchy Process Analysis (AHP) assisted by expert choice version 11.2 software.

The steps of SWOT Analysis :

1) The identification of strength and weakness factors (internal factors), opportunity and threat (external factors), in forms of IFAS and EFAS matrix.

2) The scoring and assessment on internal variable is based on Saaty scale (Saaty, 1993) with strategic value in the development of KSPP MIFEE Program Merauke including strength and weakness and strategic external variables including opportunity and threat.

3) The result of scoring and assesment on strategic factors then put in order from the highest one the result then analyzed using Expert Choice 11.2 software.

By referring to relationship matrix between strength and opportunity (S-O) and weakness and threat (W-T), the strategic steps of KSPP MIFEE Program development then are formulated.

\section{RESULTS AND DISCUSSION}

\subsection{The Identification of Strategic Factors on KSPP MIFEE program Development}

The effect of KSPP MIFEE Program development can be analyzed using SWOT by categorizing them into external factors (opportunity and threat) or can be said as direct impact. Meanwhile, indirect impact is categorized into internal factors (strength and weakness). Both factors give positive effect coming from opportunity and strength and negative effect coming from opportunity and weakness.

\subsubsection{Strength}

The explanation of each strategic factor as strength point is:

1. MP3EI program stated Papua as Food, Fishery, Energy, and Mine National Development Centre and Merauke as Food Barn
MP3EI is a government program to accelerate economic growth in Indonesia as stated in President Policy Number 32 in 2011 on Masterplan on Acceleration and Expansion of Indonesia Economic Growth (MP3EI). This program aims to make Indonesia as one of countries with big economic in 2025. Papua and Maluku Islands as the Centre of Food, Fishery, Energy, and Mine National Development.

Merauke government has strong will to realize the Centre of National Food Production (KSPPN) in Eastern Indonesia. Huge potential of Merauke needs to be maintained well to produce farming commodity and later improve social prosperity in Eastern Indonesia. So that, it needs integrated and systematic planning to optimal and continous results.

2. The potential Natural Resources (land and water supply)

The development area of KSPP MIFEE Program is located inside River Stream Area of Bian, Kumbe, and Maro rivers (DAS Bikuma). DAS Bikuma is divided into 3 parts, Upstream; Ulilin, Oligobel, and Muting District, Medium; Okaba, Kurik, Tanah Miring, Jagebob, and Sota District, Lower; Okaba, Kurik, Semangga and Merauke District. In other words, Merauke is the downstream of DAS Bikuma, especially river stream area of Maro. The stream is in the northern Merauke. The width of DAS Bikuma is $19,534.79 \mathrm{~km}^{2}$ with water resource potential of $593.6 \mathrm{~m} 3 / \mathrm{s}(3)$

3. The will of people to improve the prosperity

The relatively low economic generates the people to improve it. The will to improve it by taking advantages of shore area resources is a good strength in continous managament and conservation of shore area in the future. This will is expected to be realized wisely and continously without causing any permanent harms to shore area ecosystem.

4. Conducive atmosphere of socio-culture in the society

The socio-cultural atmosphere among people in Merauke is considered as conducive. It is shown by the relationship between the origin tribe Marind Anim and other tribes; Muyu, Mappi, Asmat, some transmigrants including from Java, Maluku and Makassar brought by government's transmigration program who are living in harmony.

\subsubsection{Weaknesses}

The explanation of each strategic factor as weakness is:

1. The absence of special team handling MIFEE Program in Merauke

The absence of special team handling MIFEE Program in Merauke causes less of data and information on development area of MIFEE Program. This little information causes difficulty for investors in getting detail information on potential and development area, so investors come and communicate directly with the owner of the land will be used as development area. This causes 
doubfulness in investors to invest in MIFEE Program Merauke area.

\section{Sectoral Management}

Sectoral management is centered to technical institution handling MIFEE Program. The development of the program is not yet integrated between each institution and another. This causes the development to run in different paths, such as; the project on Agriculture Development for Rice was handled by Agriculture Department of Merauke, while the irrigation building as supporting program of food plant of rice was handled by other government service under the ministry, and same with supporting infrastructure such as roads and bridges, , so the process happens is not connected to the area of rice field crop.

3. The dependence on central government for activities funding

The development of MIFEE Program in Merauke is very dependent on central government subvention considering the development target is huge and needs much cost. The absence of subvention from central government causes regional government to miss the program. It is concluded from the reality that the project running now is the one funded by central government.

4. Lack of skillful human resources

The quality of human resources is determined by education level and skill owned by farmers. Limited skillful human resources especially in terms of science and technology is related to industrial development project; oil palm plantation, sugar cane, and cotton; causing less of contribution in MIFEE program so the result is less than expected. Low quality of human resources especially local farmers is influenced by low education level.

\section{Social jealousy}

Based on field observation, social jealousy is commonly caused by some factors; unfinished land compensation problem between investors and family owning the land, involvement of people owning the land as workers in company operation, and different wages between local people and comers.

\subsubsection{Opportunity}

The explanation of each strategic factor as element of opportunity is;

1. The possibility to expand the croppping area

The land potential is $2.491 .821,99 \mathrm{Ha}$, with 1.9 millions Ha expandable wet-land potentential and $5.91 \mathrm{Ha}$ dry land (Food Crop Agriculture Department, 2013). Wet-land and dry-land make it possible for Merauke to expand the cropping area both for wet -land crop like beans and rice and dryland crop like coffee, rubber tree, cotton, and oil palm plantation.

2. Operational and rehabilitation fund asisstance from Central Government

MIFEE Program making Merauke as national food supply as stated in government policy named as Masterplan on Acceleration and Expansion of
Indonesia Economic Growth (MP3EI) and implied by giving operational ad rehabilitation funding aimed to accelerate the process of program operation.

\section{The possibility on farming diversification}

Diversification can be done in two ways; 1) create more farming activities except chicken breeding and fishery 2) add more various plants on one farming land, for example by planting corn on area of ricefield (tumpangsari system), or planting plantation crop among farming crop or using the land to develop cattlebreeding.

4. The use of new technology to improve farming productivity

The use of new technology to improve farming productivity at the development of MIFEE Program in Merauke is important in consideration of area width; 1.2 million hectares. The new technology used such as modern farming tools (land clearing, planting and harvesting tools), best quality seeds, various fertilizer and chemical drugs to improve productivity and overcome pest.

\section{The law protection}

The law foundation of KSPP MIFEE Program development is President Rules Number 32 2011 on Masterplan on Acceleration and Expansion of Indonesia Economic Growth (MP3EI), which is renewed by President Rules Number 4820144 on the replacement for President Rules Number 322011 on Masterplan on Acceleration and Expansion of Indonesia Economic Growth (MP3EI) 2011-2025, stating Merauke as national food supply source and mine in Eastern Indonesia by considering the potential of area with flat topography and fertile soil.

6. The compatibility with Regional Policy RTRW Merauke Regency

Merauke Government thorught RTRW program has issued the development area of KSPP. Huge land need is aimed to avoid cash with conservation and protection area. Regional Government of Merauke issued Regional Policy Number 14 in 2011 about the Planning of Spacial Area Merauke regency.

7. The investors supporting MIFEE Program Merauke

The investors will to invest their money to Farming Production Centre Cluster (KSPP) MIFEE Program is really high. The report from Investment Agency and Integrated Permission Service in 2016 stated investors interested in investing their money to KSPP MIFEE are 32 companies in fields of ; 8 sugar cane plantation companies, 8 oil palm plantation companies, 3 food crop development companies, 8 IUPHHK-HTI development companies, 1 industrial wood shale company, 1 clean water development company, 1 electrical and engineering company, and 1 IUPHHK- HA company.

\subsection{Threat}

The explanation of each strategic factor as element of threat is; 


\section{Land conversion for non-farming activities}

Land conversion is considered as a result from land development. Mostly, land conversion is aimed to fulfill the needs caused by population growth leading to demand on higher life quality. Land conversion in Merauke is unavoided. The clearing land for MIFEE program causes demand on land and job fields. The increase numbers of workers runs consequently with the higher demand on residence. Therefore; the land used to be purposed as farming conservation is changed to residence and industry.

\section{Environment polution}

The land spared for MIFEE program in Merauke is 1.2 million hectares where $\pm 90 \%$ comes from land clearing in forest. This change of function from forest to plantation affects the amount of glasshouse emission produced as big as 228 thousand tons $\mathrm{CO}_{2} \mathrm{e}$. It is as much as $30 \%$ of Carbon in natural forest in eastern Indonesia. This farming expansion program will burden government in reaching the target of reducing gas emission as much as $26 \%$ in 2020.

3. Water demand increase

1.2 million hectares Land conversion from forest to monoculture plant for MIFEE Program causes decrease in water level debet and increase surface runoff. (4) Stated the decrease of debet because of land conversion into monoculture plant is caused by the difference water demand between forest and monoculture plant which influencing the value of water surplus and leading to debet changing. The water demand in huge amount for plantation will influence water debet on rivers nearby. This will affect people activities who use rivers as spring and living source.

Stated the change in land using pattern affect the decrease of water availability due to higher seasonal fluctuation signed by flood and extreme drought (5). The change on land using by expanding water-resist surface causes lack of infiltration, decrease underground water recharge, and increase runoff. The decrease of water surface will directly affect decrease on water debet and increase on runoff and increase of debet

\section{Loss and damage bio-diversity}

During 2005-2006, the damage on tropical forest reached 59.3 million Ha from 127 million $\mathrm{Ha}$ total Indonesian Forest causing 30\% species of tropical forest flora and fauna extinction. Stated about 4 to 8 percents from the exist species will be extinct in the next 25 years (6). The process of land conversion giving biggest impact to the loss of bird species, endemic flora and fauna, and the damaged ecosystem is land clearing. Land clearing activity causes many endemic flora and fauna extinction and habitat fragmentation and the occuring of brand new habitat.
Based on field observation, there are some factors causing the decrease on number of agricultural workers; (1)Internal factor that is economic aspect where farmer is a high risk job due to unpredictable season causing the production of crop to be unreliable to meet the needs of living (2) External factor that is unpredictable nature factor and converted function of land from farming to nonfarming.

\section{The importance and social conflict}

The importance and social conflict during MIFEE Program in Merauke is irressistable. It is because the area is huge. The observation result showed the development is highly conflictual. Various resistence to reject MIFEE Program came from local, scholars, researchers, and nongovernmental organizations. The occuring resistance shows conflict happening in socio-environmental conflict dimension. The resistance showing up is commonly related to social and environmental changing as the results from importance crash in viewing land maintainance rights. Land is viewed by locals as primary needs to fulfill daily needs of food which then is crashed with land authorities of some companies with concession permission in the scheme of food estate development.

\subsection{Internal-External Matrix}

Based on analysis results, the priority of SWOT components in terms of KSPP development in order are; Internal factors of Strength with score 0.483 $(48.30 \%)$, weakness with score $0.120(12.00 \%)$, and external factors of opportunity with score 0.272 (27.20 $\%)$ and threat score $0.124(12.40 \%)$. The priority of SWOT components of Farming Production Centre Cluster (KSPP) MIFEE Program in Merauke are shown in Table Figure 1.

Model Name: HASIL ANALISIS AHP-SWOT KSPP PROGRAM MIFEE KAB

Priorities with respect to:

Combined

Strategy developing Farming Production Centre Cluster (KSPP) MI...

Strength
Weakness
Opportunity
Threat
Inconsistency $=\mathbf{0 . 0 0 8 6 4}$
$\quad$ with 0 missing judgments.

Figure 1. The rank of Priority in developing Farming Production Centre Cluster (KSPP) MIFEE Program in Merauke

To know the composition between the SWOT components, the scoring based on Saaty scale is done in accordance with each keyperson opinion. The scoring results are shown in Table 1

\section{The reluctant to work on agricultural sector}


Table 1. Identification of Internal and External Factors with SWOT

\begin{tabular}{l|l|l}
\hline \multicolumn{1}{c|}{ Strenth } & Score & Rank \\
\hline $\begin{array}{l}\text { MP3EI stated Papua as the national } \\
\text { centre of Food Supply, Fishery, } \\
\text { Mine and Energy development, and } \\
\text { Merauke is food supply barn (S1) }\end{array}$ & 0.351 & $\mathrm{P} 1$ \\
\hline $\begin{array}{l}\text { Natural resource potential (land and } \\
\text { water supply) (S2) }\end{array}$ & 0.307 & $\mathrm{P} 2$ \\
\hline \multicolumn{1}{c}{ Weakness } & & \\
\hline $\begin{array}{l}\text { The little number of skilfull human } \\
\text { resource }\end{array}$ & 0.269 & $\mathrm{P} 1$ \\
\hline $\begin{array}{l}\text { The absence of special team handling } \\
\text { the case }\end{array}$ & 0.232 & $\mathrm{P} 2$ \\
\hline $\begin{array}{l}\text { The investors supporting MIFEE } \\
\text { Program Merauke }\end{array}$ & 0.163 & $\mathrm{P} 1$ \\
\hline $\begin{array}{l}\text { The use of new technology to } \\
\text { improve farming productivity }\end{array}$ & 0.160 & $\mathrm{P} 2$ \\
\hline & & \\
\hline $\begin{array}{l}\text { The investors supporting MIFEE } \\
\text { Program Merauke }\end{array}$ & 0.163 & $\mathrm{P} 1$ \\
\hline $\begin{array}{l}\text { The use of new technology to } \\
\text { improve farming productivity }\end{array}$ & 0.160 & $\mathrm{P} 2$ \\
\hline
\end{tabular}

Source: Data Analysis Results, 2017

Based on Table 1, the Internal factor component (Strength) with highest score is the existence of MP3EI stating Papua as the national centre of Food Supply, Fishery, Mine and Energy development, and Merauke is food supply barn (0.351) and the existence of Natural resource potential (land and water supply) (0.307). The analysis results of Weakness show the highest score coming from leack of skill full human resources (0.269), and the absence of special team (0.232).

External factor of opportunity with the highest analysis score is the investors supporting MIFEE Program Merauke (0.163) and the use of new technology to improve farming productivity $(0.160)$. While the external factor of threat is the importance and social conflict (0.245) and the loss and damage of bio-diversity (0.224).

The strength factor has total score of 3.658, while weakness has total score of 1.502 , the score of opportunity factors is 2.323 and threat factor is 1.245 . From those, we can determine the coordinate on cartesius diagram to get the proper strategy to develop KSPP MIFEE Program in Merauke continuously. Coordinate $(\mathrm{X})$ is on 2.156, and coordinate $(\mathrm{Y})$ is on 0.539 showing main strategy position mentioned as growth strategy. The development of MIFEE Program is considered to be in profitable position. The strength factors of KSPP MIFEE Program can make use of opportunity factors to help the continuous development of KSPP MIFEE Program.

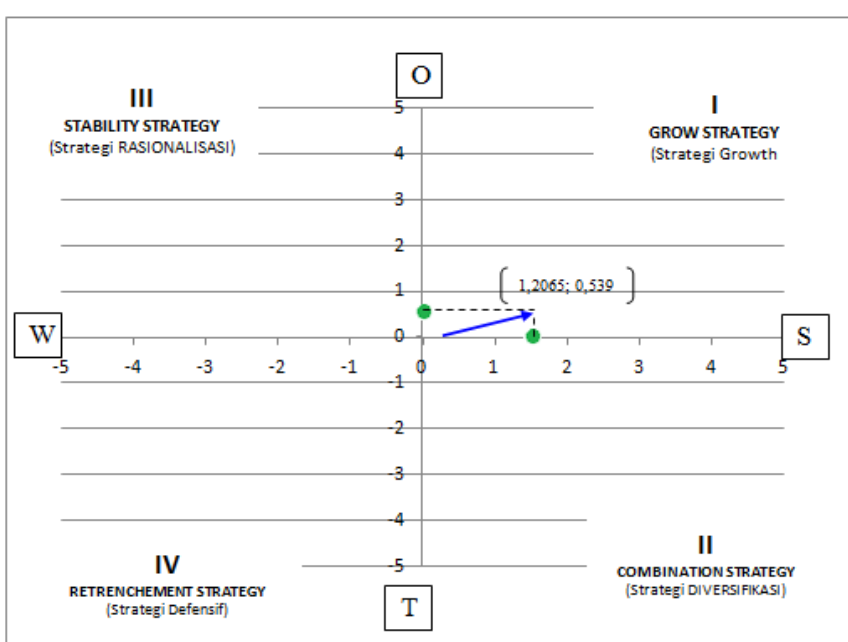

Source: Data Process Result, 2017

Figure 2. Cartesius Diagram of AHP- SWOT

\subsection{Recommeded Strategy of Farming Production Centre Cluster (KSPP) MIFEE Program in Merauke Development}

1. Strategy I. Forming special team to manage KSPP MIFEE Program of Merauke involving all stakeholders to support national food supply, reduce regional dynamics, and receive locals' aspiration.

According to the result of field analysis, MIFEE Program nowadays has not run as expected because of some complex obstructions and different perception between investors, government, and local people. The data from BPMP2T of Merauke in 2016, from 32 investors; 12 companies have operated, 15 of them are active but not yet operated and 5 are inactive companies (7). The questions from special rights people (hak ulayat) about land ownership and the compensation dominantly handled by investors (PMDN dan PMA) can trigger ownership conflict, socio-cultural conflict, and the availability of structures and infrastructures of farming, technology and political issues which can obstruct the MIFEE Program development.

Considering the usefulness of MIFEE Program to increase independence and national nobility on national food supply, Regional Government of Merauke has strong will to realize National Farming Production. Centre Clusters (KSPPN) in Eastern Indonesia. Huge potential of Merauke needs to be managed well to produce farming commodity boosting people's prosperity in eastern Indonesia. So that, there is need to form a team or agency specially managing KSPP MIFEE Program to straighten commitment on National Food Politic, reduce dynamics and its effects, and receive people with ownership rights' aspiration. 


\section{Strategy II. Introducing KSPP MIFEE Program to local people.}

Introduction to KSPP MIFEE Program is considered important to help understanding to stakeholders, government, privates (investors), people with ownership rights, and development supervisor. It is important so all aspects can understand the meaning and aim of the KSPP MIFEE Program development.

The socialization of KSPP MIFEE Program development is meant to put perception, assessment, understanding, and steps on the same page to development food estate. It is started from regency level to village level. It is considered important as the beginning step since the development involves many aspects and importance. The target of the socialization is regional government board, private, and local people in general, especially those living around KSPP MIFEE Program.

The socialization can be done in formal and informal approach. The former is related to direct socialization through workshops, public consultation, or focus group discussion by involving all stakeholders on level of regency, districts, and village so there is no one feeling left behind and this must be done continuously so they can understand the meaning and purposes of this development program. Informal approach can be done through religious activities at churches, mosques, women's activities, etc. Socialization can also be done by involving government from the level of districts, or villages through cooperation with self-funded agencies to give understanding with interpersonal approach.

1. Strategy III. Improving the ability, skill, and human resources capacity and getting supported through local-wisdom-based education.

The management of KSPP MIFEE Program requires 2 aspects; natural resources and human resources. Both resources are prominent to determine the success of the KSPP MIFEE Program development in Merauke. Stated that human resources is more important aspect than natural resources one (8)..

Argued that local wisdom is all form of knowledge, belief, understanding, custom, or ethics leading human's attitude in ecological community (9) Hence; local wisdom is all values, custom, culture, experiences, characters in society inherited to younger generation to another and will stick to some of the society.

\section{Strategy IV. Developing technology to improve} eco-friendly farming productivity and diversification with low-input to reduce people's resistance.

Farming technology is an application of scientific principles in terms of making use of farming and natural resources economically for human's wealth; (10)

The application of farming technology to improve production are; Penerapan teknologi pertanian untuk meningkatkan produksi pertanian antara lain:

1. Using excellent seeds
2. Chemical fertilizer

3. Modern farming tools

\section{CONCLUSION AND RECOMMENDATION}

\subsection{Conclusion}

Development strategy for KSPP MIFEE Program of Merauke is Rapid Growth Strategy. This is suitable with location of KSPP MIFEE Program of Merauke requiring progressive strategy which can be implemented; 1) Forming special team to manage KSPP MIFEE Program of Merauke involving all stakeholders to support national food supply, reduce regional dynamics, and receive locals' aspiration.; 2) Introducing KSPP MIFEE Program to local people; 3) Improving the ability, skill, and human resources capacity and getting supported through local-wisdom-based education; 4) Developing eco-friendly farming diversification with low external input to reduce people resistance; 5) Involving stakeholders (government, investors, and society) to develop KSPP MIFEE Program of Merauke; 6) Implementing rules and punishments based on legal policies to maintain the condition of environment at KSPP MIFEE; 7) Involving people with special rights (hak ulayat) into Corporate Social Responsibility (CSR) activities.

\subsection{Recommendation}

1. Forming special team for Merauke Food Crop Area which has authority to manage food estate supported by universities to strengthen planning, implementation, cross-sectional coordination, crossagency, and custom society also self-funded agency as guidance in program operation at field.

2. To make the development of Farming Production Centre Clusters (KSPP) MIFEE Program of Merauke run well, the existence of local people with their ownership rights must be respected and keep involving them in the development program.

\section{References}

1. Coordinator Ministry of Economic Sector on Acceleration and Expansion of Indonesia Economic Development Masterplan (MP3EI) 2011. Coordinator Ministry of Economic Sector (2011)

2. Budiningsih, W. Pemberdayaan Petani Melalui Penguatan Modal kembagaan Petani di Kawasan Agropolitan Kecamatan Belik Kabupaten Pemalang (2015) Jurnal Agriekonomika, Vol 4(1), hal. 50-58.

3. Balai Wilayah Sungai Papua, 2012. Laporan Finalisasi Penyusunan Rancangan Pola Pengelolaan Sumber Daya Air Wilayah Sungai Einlanden-Digul bikuma, 2012 . Balai Wilayah Sungai Papua, Jayapura. 
4. Onrizal, 2005. Hutan dan Pengaturan Tata Air. at: https://www.researchgate.net/ publication/ 42320172. e-USU Repository (C2005 Universitas Sumatera Utara Diakses pada 15 Januari 2018. 10 p.

5. Pawitan, H. Perubahan Penggunaan Lahan dan Pengaruhnya terhadap Daerah Aliran Sungai. Bogor: Laboratorium Hidrometeorologi FMIPA IPB (2002).

6. Gindo N. Harga yang Mesti Dibayar Akibat Perkebunan Kelapa Sawit Skala Besar. (2009) Artikel. www.kpsmedan.org.

7. Badan Penanaman Modal dan Pelayanan Terpadu (BPMP2T). Laporan Realisasi Kegiatan Penanaman Modal di Kabupaten Merauke 2016. Badan Penanaman Modal dan Pelayanan Terpadu (BPMP2T) Kabupaten Merauke (2016).
8. Notoatmodjo, S. 2013. Pengembangan Sumberdaya Manusia. Jakar: Salemba Empat

9. Keraf, 2002. Etika Lingkungan. Jakarta Buku Kompas

10. Mangunwidjaja, D. dan Sailah, I. Pengantar Teknologi Pertanian. Penerbit Penebar Swadaya. Bogor. (2009).

11. Freeman, R. E.. Strategic Management:A Stakeholder Approach. Pitman Publishing, Boston (2010)

12. Gunn, A. Clare, Tourism Planning: Basics, Concepts, Cases/Third Edition, Taylor \& Francis 